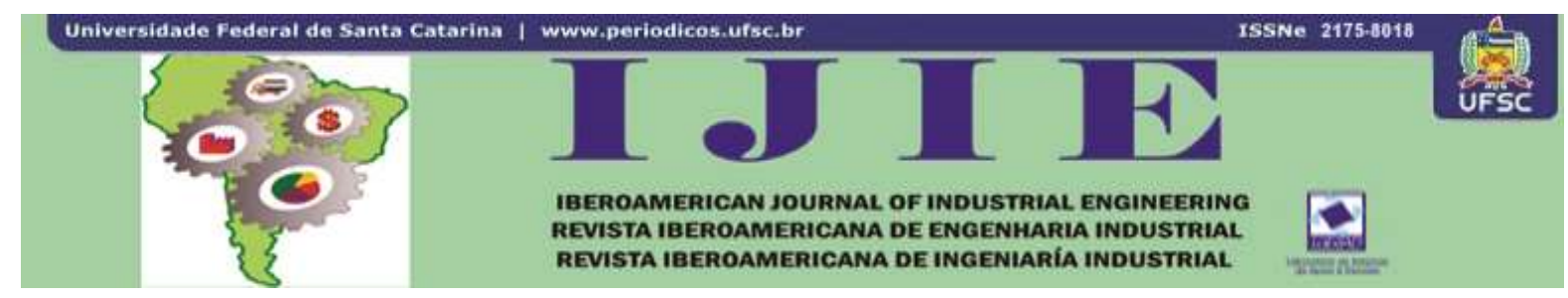

\title{
GLOBAL SOURCING MANAGEMENT OF MULTINATIONAL COMPANIES IN EMERGING MARKETS: THE CASE OF BRAZILIAN SUBSIDIARIES
}

\author{
Marcelo André Machado ${ }^{1}$ \\ Alexandre Ricardo ${ }^{2}$
}

\begin{abstract}
The growing competition for consumer in emerging markets has required from multinational companies (MNC) strategies to support this new business conditions. In this context, it is highlighted the importance of strategies alignment and mutual reinforcement between MNC headquarters and subsidiaries in the supply management. The aim of this article was to analyze how foreign multinational company subsidiaries operating in emerging markets like Brazil are embedded and attend MNC global sourcing strategies. A multiple case study research has been conducted in eight Brazilian subsidiaries of MNC through in-depth interviewing with local supply managers and a documentary research was made. It was identified that Brazilian production subsidiary participation is partially aligned with the strategy of MNC global sourcing. The results suggest that subsidiaries in emerging markets should review its approach related to the global sourcing management, becoming more proactive, aligned with the MNC global sourcing strategy, as well as serving in their level of expertise.
\end{abstract}

Keywords: Production subsidiaries. Supply strategies. Global Sourcing. Multinational companies. Emerging markets.

\section{INTRODUCTION}

The growing competition for consumer markets on a worldwide basis, greater agility to the new products development and launch of new products and increasing demands from customers have been demanding from companies to develop strategies to support these new business conditions. Thus, a possible alternative for companies is to adopt internationalization strategies with overseas production.

\footnotetext{
${ }^{1}$ Doutor em Administração/Marketing, Professor e pesquisador do Programa de Mestrado Profissional em Gestão e Negócios-MPGN/UNISINOS, Coordenador do MBA em Negócios e Empreendimentos Internacionais/UNISINOS, Consultor de empresas, Brasil, mmachado@unisinos.br.

2 Mestre pelo Programa de Mestrado Profissional em Gestão e Negócios-MPGN/UNISINOS, Profissional de Supply Chain, Universidade do Vale do Rio dos Sinos-UNISINOS, Brasil, aricardo@mideacarrier.com.
} 
Internationalization strategies are present in the growth plans of key executives. Research Foundation for the Malcolm Baldrige National Quality Award revealed that three of the five major objectives faced by Executive Officers (CEOs - Chief executive officers) are related to globalization. The research also highlights that $95 \%$ of CEO's reports that increasing internationalization of the company is the main strategy to be developed into a five-year horizon (MONCZKA; TRENT, 2003a). This strategy has a direct impact on the flow of foreign investment.

According to the World Investment Report 2011, while that in the period 1990 to 2000 , foreign direct investment (FDI) worldwide was $\$ 490$ billion (annual average) in 2010, it reached U.S.\$ 1.24 trillion. International production is growing, through sales to foreign markets, increase employment and investments of multinational companies (MNCs). These companies brought value added to the economy in order approximately $25 \%$ of gross domestic product (GDP). The study also highlights the importance of significant subsidiaries of these transnational corporations, which accounted for $10 \%$ of global GDP and $30 \%$ of exports. In 2010, for the first time, developing countries and transition economies together accounted for more than half of global FDI flows (WORLD INVESTMENT REPORT, 2011).

The change in the FDI flow is verified with more representation in developing and transition economies. Consolidated data of 2010 compared to 2009, point out that, from 20 countries that received the largest FDI inflow, 10 are based in these regions, and in 2009 this number was 7 countries. Brazil is in the fifth place, behind only China in the BRIC countries (Brazil, Russia, India, China). Projections to period between 2011 and 2013, related to the 20 countries with higher FDI flows, emphasize that Brazil will move from fifth to fourth in the world, being the first choice in Latin America, ahead of Russia in BRIC (WORLD INVESTMENT REPORT, 2011).

The evolution of these actions and business strategies, as the establishment of a new production unit, or even the increments of productive capacity, demands from the companies, strategic analysis in terms of supply format. Increasingly, there is adoption of make or buy analyzes. Studies highlight that companies have increased outsourcing of its operations, demanding a greater proportion of materials, components, sub-assemblies from external companies, or even other subsidiaries of the group, reaching, in some cases, $60 \%$ of the cost of the final products manufactured (KRIPPEL; ANTUNES, 2003; CAPS RESEARCH, 2011). These data validate and emphasize the importance of supply management as a strategic part of 
the organization, providing secure maintenance of operating in different markets and sustainable growth of the business.

Information presented emphasizes the importance of MNCs to the world economy as well as the representativeness of its subsidiaries, and the emerging countries. In this scenario, it is needed to implement efficient methods of management of the subsidiaries allocated in different regions, in particular the supply management on a worldwide basis, due to its strategic importance to the safety of the manufacturing operations, as well as the significance in terms competitive in cost. Monczka and Trent (2003a) corroborate with this, highlighting companies that succeed will be those that learn how to best leverage and coordinate their activities in the supply chain on a global basis. For many, this includes having global supply strategies and processes that integrate design, supply, production, logistics and marketing. Hartmann, Trautmann and Jahns (2008) corroborate with Monczka and Trent (2003a), highlighting that the globalization of industries, accompanied by changes in the structure of competition has forced many MNCs to adopt the strategy of global sourcing (GS).

According to Kotabe and Murray (2004), the strategy of GS involves management (1) logistics, identifying which production unit is more capable and how the components will be provided to the production, (2) interfaces between R\&D (Research and Development), manufacturing and marketing on a worldwide basis. In essence, the main objective of the GS strategy is to exploit the competitive advantages (skills in $\mathrm{R} \& \mathrm{D}$, production and marketing) and comparative (cost of labor, mineral resources, government incentives) of different countries, both in internal processes and in suppliers.

Companies adhering to the GS achieved cost savings in the procurement of raw materials $15 \%$, on average, reaching in some cases $30 \%$, compared to domestic purchases. Additionally, it was identified improvements in quality, level of service and response from suppliers, and technological contribution. The development of processes for compliance with this format supply management put the company on a new level of performance (MONCZKA; TRENT, 2003a).

The strategy of global sourcing is usually defined in multinational companies for their World Headquarters (WHQ). These settings are transferred to the subsidiaries in the form of specific demands, where the production units meet what is required (KOTABE, 1998; MONCZKA; TRENT, 2003a; KOTABE; MURRAY, 2004; NASSIMBENIS, 2006; HARTMANN; TRAUTMANN; JAHNS, 2008). It is understood that better alignment of 
overall strategy needed to be put in place, and understanding by the subsidiaries over the limits of their contribution as well as the extent of their role within the strategy.

In the bibliographies studied, it was found that the research has been focused on the analysis of GS management in the companies WHQ, or even in the main subsidiaries of the group, based in developed countries, especially the United States and Europe. Due to the growth and representation of developing countries in the global economy, it is understood as necessary to identify how the subsidiaries of multinational companies based in countries called as emerging economies, such as Brazil, are involved and contribute to the overall strategy.

The present study aims at examining how the production subsidiaries of foreign multinational companies operating in Brazil are involved and participate in the global sourcing strategy of the organization. To meet this objective, the multiple-case study was adopted as a method, using semi-structured interviews in depth with local supply managers, and documentary research. The sample was composed of eight foreign multinational companies with production units in Brazil.

To facilitate the understanding of the paper is structured as follows: in the second section presents the literature review that supported the research. Then, the research method is described. The fourth section presents the analysis of results. Finally, it is presented the concluding remarks and directions for future studies.

\section{GLOBAL SOURCING}

Studies on global sourcing has gained notoriety and a significant increase of interest among researchers in the field of purchase publications (MONCZKA; TRENT, 2003a; KOTABE; MURRAY, 2004; LINTUKANGAS; PELTOLA; VIROLAINEN, 2009; BARRAT; CHOI; LI, 2011; HULTMANN et al., 2012). According to Hultman et al. (2012), definitions for global sourcing are varied, but one can summarize them as integration and coordination of supply strategies on a global scale.

Global sourcing differs from international buying in scope and complexity, having proactively integrating and coordinating products and raw materials, designs, technologies, common suppliers on a worldwide basis. This includes engineering activities, and production operations. The Global Sourcing strategy demands horizontal integration between the development of the product concept, project teams, production planning, and supply chain at different levels. International Purchasing can be characterized as a commercial transaction 
between buyer and seller are located in different countries (TRAUTMANN; BALS; HARTMANN, 2009). This type of process is typically more complex than buying domestic (MONCZKA; TRENT, 2003a; STEINLE; SCHIELE, 2008).

Global sourcing often involves management (1) logistics, identifying which unit is more capable and productive as the components will be provided to the production, (2) interfaces between R\&D (research and development), manufacturing and marketing on a worldwide basis. In essence, the goal of the strategy of global sourcing is to exploit the competitive advantages (skills in $\mathrm{R} \& \mathrm{D}$, production and marketing) and comparative (cost of labor, mineral resources, government incentives) of different countries, both in internal processes, as for suppliers (KOTABE, 1998; KOTABE; MURRAY, 2004).

Hartmann, Trautmann and Jahns (2008), in their literature review, propose that global sourcing includes not only integration and coordination of procurement requirements between production units in different regions and countries, but maintaining compliance with the premises of the local market demands governmental, cultural and economic.

Through bibliographies surveyed, it was identified the importance of the strategy of GS, both in terms of practical applications in several industries, as in the academic field where different authors, from different nationalities, have sought to present their studies and contributions.

However, it was identified the lack of a form of consolidation and presentation of bibliography, to give the reader a better understanding of the main issues that involve the adoption of this strategy. Different studies have researched part of information that make up the whole of the strategy, such as conceptualization, key motivators, forms management and results. Thus, Figure 1 presents a consolidation of the main information of the theoretical study on the strategy of global sourcing, presenting a synthetic form and aims to represent the main constructs of this article. 
Figure 1 - Global Sourcing: summary

\begin{tabular}{|c|c|c|c|c|c|c|}
\hline \multicolumn{7}{|c|}{ Clobal Sourcing - Sunmary } \\
\hline Cencept & \multicolumn{5}{|c|}{ 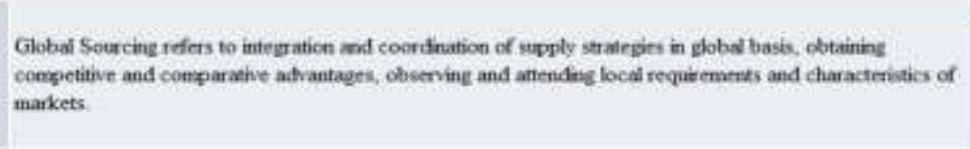 } & 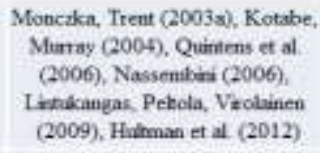 \\
\hline Deivers & \multicolumn{5}{|c|}{ 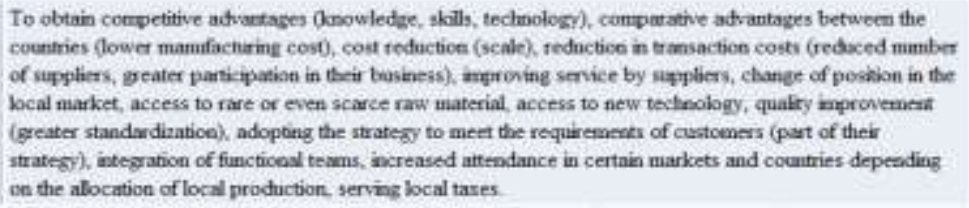 } & 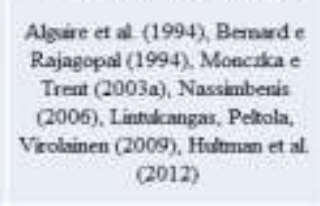 \\
\hline $\begin{array}{l}\text { Procurement } \\
\text { finction stagea }\end{array}$ & $\begin{array}{l}\text { Level } 01: \\
\text { Engaged in } \\
\text { domestic purchase } \\
\text { only }\end{array}$ & $\begin{array}{l}\text { Level } 02 \\
\text { Engaged in } \\
\text { inemisional } \\
\text { purchase, as } \\
\text { needed } \\
\text { (International } \\
\text { buinin) }\end{array}$ & 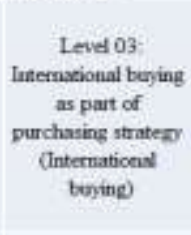 & $\begin{array}{l}\text { Level } 04 \\
\text { lestegradion and } \\
\text { coodinatioe of } \\
\text { plobal sourcing } \\
\text { strategies across the } \\
\text { worldaside boving } \\
\text { locations (Global } \\
\text { Souncing) }\end{array}$ & $\begin{array}{l}\text { Level 05: } \\
\text { Iftegration and } \\
\text { cocerdinxion of } \\
\text { gobal saurcing } \\
\text { strafejies with other } \\
\text { finctiond teams } \\
\text { (Global Sourcing) }\end{array}$ & $\begin{array}{l}\text { Moncikat, Trent (2003a), a parti } \\
\text { do sivel 05, adopilo ao modelo de } \\
\text { integrag to entre Marketing. } \\
\text { Engenharia, Marufatura proposto } \\
\text { por Kotabe (1995) }\end{array}$ \\
\hline $\begin{array}{l}\text { Strasegle } \\
\text { sourcing } \\
\text { decisioess }\end{array}$ & $\begin{array}{l}\text { Intrafirm sourcing - } \\
\text { Someibc or } \\
\text { imported from } \\
\text { company facĭties }\end{array}$ & $\begin{array}{l}\text { Outsourcine - } \\
\text { domestic of } \\
\text { imported, using } \\
\text { ami's length of } \\
\text { strategic partnership }\end{array}$ & & & & $\begin{array}{c}\text { Jarillo (1993), Kotabe }(1998) \text {, } \\
\text { Kotabe, Murray }(2004) \text {, }\end{array}$ \\
\hline $\begin{array}{l}\text { Orferisabonal } \\
\text { devien, plobal } \\
\text { sourciag } \\
\text { management }\end{array}$ & $\begin{array}{l}\text { Feil decentralization } \\
\text { (transactional } \\
\text { oremerition) }\end{array}$ & $\begin{array}{l}\text { Deceotratized bot } \\
\text { coordininted (sjobal } \\
\text { coordination) }\end{array}$ & $\begin{array}{l}\text { Centratized } \\
\text { managenent for } \\
\text { gobal (gbbal } \\
\text { erganizatica) }\end{array}$ & $\begin{array}{l}\text { Functional group } \\
\text { specielizint in } \\
\text { foreign matrkets }\end{array}$ & & $\begin{array}{c}\text { Arnold (1999), Leinonen (1999), } \\
\text { Bemard e Rajagopal (1994), } \\
\text { Cunipero e Monctka (1997). } \\
\text { Mooczla e Trent (2003a), } \\
\text { Hartumann, Gertard, Ctristopber } \\
\text { (2008) }\end{array}$ \\
\hline $\begin{array}{l}\text { Catrgoties and } \\
\text { mechinisems of } \\
\text { control }\end{array}$ & $\begin{array}{l}\text { Pessonal } \\
\text { centraltsed control } \\
\text { (Direct/ ecolicit }\end{array}$ & $\begin{array}{l}\text { Bureaucratic } \\
\text { formalsed coeerol } \\
\text { (Inwerscond / }\end{array}$ & $\begin{array}{l}\text { Output control } \\
\text { (lmpersond / } \\
\text { intelicit }\end{array}$ & $\begin{array}{l}\text { Control by } \\
\text { socialisation and } \\
\text { netwodss }\end{array}$ & & $\begin{array}{l}\text { Harzing (1999), Hartanam. } \\
\text { Gerhard, Christopber (2008) }\end{array}$ \\
\hline Rosks: & $\begin{array}{l}\text { Noed for toare accur: } \\
\text { imposed by countries } \\
\text { in the global strategies }\end{array}$ & $\begin{array}{l}\text { An forecants of prodtr } \\
\text { to protect the local nz } \\
\text { s, logistical complesir }\end{array}$ & $\begin{array}{l}\text { iction, pobbical instakil } \\
\text { arket, foreign exchan } \\
v, \text { increase invertocy. }\end{array}$ & $\begin{array}{l}\text { aty between nabons, te } \\
\text { tge variation, adtherence }\end{array}$ & $\begin{array}{l}\text { estrictions / barriers } \\
\text { e of production units }\end{array}$ & 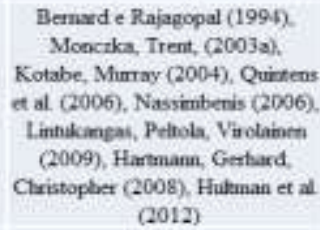 \\
\hline Success factors. & $\begin{array}{l}\text { Gowemance, policies, } \\
\text { procedures, robust pr } \\
\text { Mamifachurisg, Purch } \\
\text { technology (data cons } \\
\text { signibiant opportuniti } \\
\text { the complexity of the: } \\
\text { suppbiers for conplian }\end{array}$ & 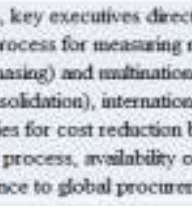 & 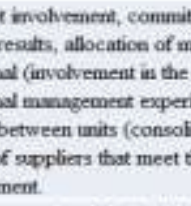 & 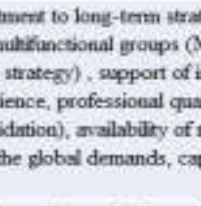 & 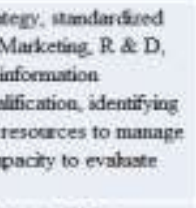 & $\begin{array}{c}\text { Bernird e Rajagopal (1994), } \\
\text { Monczka e Trent (2003b), } \\
\text { Hartmuan, Gertiard, Chriatopher } \\
\text { (2005), Lintukangas, Pehola. } \\
\text { Virolainen (2009) }\end{array}$ \\
\hline Results & $\begin{array}{l}\text { Reduction in purchase } \\
\text { average) improvensen } \\
\text { and delvery } 5 \% \text { (aver } \\
\text { Main benefits identifie } \\
\text { Greater aligumects and } \\
\text { reduction of cost/ pri } \\
\text { relationships, better v } \\
\text { iresponses, quality, d } \\
\text { acquisition process, in } \\
\text { and security of supply }\end{array}$ & 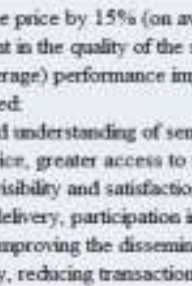 & 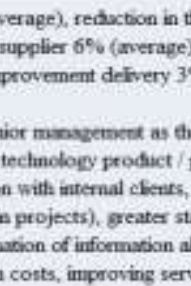 & $\begin{array}{l}\text { the total cost of owners } \\
\text { increase in cycle tine } \\
\text { 9. (co average) } \\
\text { process improvement } \\
\text { supplers performatice } \\
\text { androdization and cons } \\
\text { long the supply chain, } \\
\text { vice to emvirotmental is }\end{array}$ & 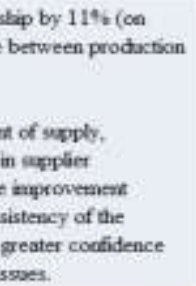 & $\begin{array}{l}\text { Bemard e Rrjagopal (199-), } \\
\text { Monczka e Trent (2003b), } \\
\text { Linukangas, Pekola, Vrohinen } \\
\text { (2009) }\end{array}$ \\
\hline
\end{tabular}

\subsection{Procurement Function Stages}

Performing analysis in the existing theories, it was identified that many studies on the process of GS sought to present formats for implementation, however, the stage model proposed by Monczka and Trent (2003a) obtained greater acceptance, being the basis for this study. 
Through extensive exploratory research, called The Global Sourcing Research Project, sponsored by the Global Benchmarking Initiative (GBI), with attendance of 162 companies from different nationalities and segments, with average sales between $\$ 1$ and $\$ 3$ billion completed in 2001 authors Monczka and Trent (2003a) developed a model that is in five stages, the evolution of the purchasing process in companies from using domestic purchases up to the level of Global Sourcing. The following paragraphs describe the stages above.

At level 1, the process and purchasing strategy is designed and directed for domestic purchases, and prioritization in regional service. The use of products from foreign sources is accomplished through imports by their suppliers (MONCZKA; TRENT, 2003a). Stages 2 and 3 are characterized in the literature researched as International Purchasing.

In stage 2, the companies now perform international purchases, but not in regular base, only according to opportunities identified. There is a growing demand for information about potential producers in a global basis, as well as the processes involved in these transactions (MONCZKA; TRENT, 2003a).

In stage 3, companies started having an international purchase perspective. Markets and potential opportunities are identified globally; proactive measures are incorporated to supply strategy. There is a higher level of information about the evolution of the international market and exchange rates. There is involvement of senior management, which realizes the benefits of international purchasing, and supports the operation. Some companies start using purchasing offices specialized in developing suppliers in different countries (mainly low cost countries) (MONCZKA; TRENT, 2003a). Stages 4 and 5 characterize the evolution of supply management at Global Sourcing.

Level 4 comprises integration and coordination strategies for global sourcing through purchasing teams allocated in different countries, but in a sophisticated level of development strategy. The operation at this level comprises information systems with global interaction, professionals with a high level of knowledge and skills in the area, with strong mechanisms of coordination and communication of supply management, centralized structure for overall coordination of activities, senior executive responsible for the management and leadership of Global Sourcing Strategies (MONCZKA; TRENT, 2003a).

Stage 5 refers to the global integration of proactive and cross-functional teams. This integration occurs during the development of a new product or even the definition of new source of components supply and/or services for attending customer's regular demands. At this stage, supply management is directly linked to other functional groups, such as 
engineering, operations and marketing. By definition, only companies that have areas of research and development, design, production, management and global procurement can progress to this level (MONCZKA; TRENT, 2003a).

In order to the corporations obtain higher degree of return on their global sourcing strategy, it should guide actions for the following points: (1) standardization of major components, (2) developing product family (similar structure with few modifications to meet the various markets), (3) standardization of products on a worldwide basis (offer all markets, better, or more appropriate technology in relation to the demands), (4) using different positions between regions and countries for global commodities (KOTABE, 1998).

Global Sourcing is not a feasible option for many companies. These are large corporations that compete intensely for equity markets in different continents and countries. Are significantly higher ( $\$ 3$ billion in annual sales average) than those working with International Purchasing (\$800 million in annual sales average). These companies employ a large part of their annual purchases in non-domestic sources, and argue that improvements in global sourcing strategies and opportunities for cost reductions are more frequent and available in this strategy when compared to international purchasing (MONCZKA; TRENT, 2003a).

\subsection{Strategic sourcing decisions}

The sourcing strategy predisposes planning and decisions to be made about how to meet the demands of the local market and / or international. The term sourcing has been used to describe the management by multinational companies, the flow of components and final products in serving national and international markets. The strategic decisions of multinational supply can be used (1) group production units in an intra-firm basis, or (2) use an independent company (outsourcing/ subcontracting), adopting contractual basis (commonly referred to as outsourcing). Outsourcing can also consider (1) the free competition between firms in the market (arm's length) or (2) strategic partnerships (strategic partnership). In both cases, multinational companies use domestic sources of supply (domestic sourcing) and foreign (offshore sourcing) (KOTABE; MURRAY, 2004).

\subsection{Organization design and Global Sourcing management}

According to Hartmann, Gerhard, Christopher (2008), since the publications of Bartlett (1986) and Doz and Prahalad (1987), most of authors implicitly or explicitly refers 
continually to the advantages of integration and coordination in relation differentiation and responsiveness in terms of global strategy. Based on these two dimensions, three types of international strategies can be described: (1) multi-domestic strategy combining low integration and high responsiveness and local service, (2) global strategy, combining high integration and low local response, (3) strategy Transactional considering high integration and high local response.

The integration of supply management is often treated in terms of centralization decision making strategies, approvals centralized in one unit, usually the mother - and decentralization - decision making strategies, approvals held in different units. Several studies have highlighted the advantages and disadvantages of each model (LINTUKANGAS, PELTOLA; VIROLAINEN, 2009).

According to Hartmann, Trautmann and Jahns (2008), the first studies describing the implications related to organizational configuration for global sourcing service were presented by Kotabe and Omura (1989). Their research suggested change to more centralized organization with a focus directed to analyze the effect on the autonomy of WHQ decision in relation to the divisions and subsidiaries. Bernard and Rajagopal (1994) highlight the importance of central coordination and standardization of the selection process of suppliers, as well as dedicated resources and support from senior management to strategy management.

After an examination in several bibliographies, the following organizational structures for supply management were defined: (1) full decentralization (transactional organization), (2) decentralized but coordinated (overall coordination), (3) centralized management for global (global organization), (4) functional group specialized in foreign markets (MONCZKA; TRENT, 2003a; HARTMANN; TRAUTMANN; JAHNS, 2008;LINTUKANGAS, PELTOLA; VIROLAINEN, 2009; TRAUTMANN; BALS, HARTMANN, 2009; HULTMAN et al., 2012).

Several control mechanisms have been implemented by organizations and presented in studies on internationalization strategies (HARTMANN; TRAUTMANN; JAHNS, 2008) as shown in Figure 2. 
Figure 2 - Categories of control mechanisms

\begin{tabular}{|c|c|c|}
\hline & $\begin{array}{c}\text { Personal/cultural } \\
\text { (founded on social interaction) }\end{array}$ & $\begin{array}{c}\text { Impersonal/bureaucratic/technocratic } \\
\text { (founded oninstrumental artefacts) }\end{array}$ \\
\hline Direct/explicit & $\begin{array}{c}\text { Category 1: Personal } \\
\text { centralised control }\end{array}$ & $\begin{array}{c}\text { Category 2: Bureaucratic } \\
\text { formalised control }\end{array}$ \\
\hline Indirect/implicit & $\begin{array}{c}\text { Category 4: Control by } \\
\text { socialisation and networks }\end{array}$ & Category 3: Output control \\
\hline
\end{tabular}

Source: Adapted from Hartmann, Trautmann and Jahns (2008).

A review of the literature described in the previous sections formed the theoretical basis for revising the objectives of the study and provided the definitions for major checkpoints in the selected sample. Following are described the methods and procedures adopted for the research

\section{METHOD}

The qualitative research paradigm was chosen for the development of this study, which is justified by providing better insight and understanding of the problem. Barrat, Choiand and Li (2011) emphasize the usage of a depth approach investigation on a contemporary and complex phenomenon such global sourcing. Qualitative research is appropriate when facing a situation of uncertainty, when conclusive results differ from expectations (YIN, 1981; EISENHARDT, 1989; SIGGELKOW, 2007).

Regarding the procedure used, it was opted for multiple-case study, due to the need to check the practices adopted for managing global sourcing directly in production subsidiaries located in Brazil. According to Eisenhardt (1989), the case study is focused in understanding dynamics present within single settings. The following criteria were established for selecting the unit of analysis:

- Subsidiaries of foreign multinationals with production units in Brazil;

- Multinational companies producing and marketing its own product;

- Large company according to Brazilian classification: Gross operating revenue over US\$ 300 million (BNDES, 2012) and more than 499 employees (SEBRAE, 2012).

In this paper, the units of analysis were selected according the above mentioned criteria and convenience in terms of viability of visits and interviews. The respondents were people with higher hierarchical level in relation to procurement management within the MNC subsidiary in Brazil. Based on that, the units of analysis included a group of eight foreign 
multinational companies with production units in Brazil. To protect the identity of the companies in this study, by request of the respondents, the identification of companies was conducted through letters (between $\mathrm{A}$ and $\mathrm{H}$ ), being characterized by its segment.

In terms of procedure, it was decided to conduct in-depth personal interviews, adopting for that semi-structured form questions in order to provide greater freedom to the interviewee in the presentation of information, as well as the researcher the possibility to adjust the interview script as the realization of this.

Data collection was conducted between June and September, 2012. The interviews were recorded through notes by the researchers, being supplemented and revised following the interviews. Additionally, it was have verified documentary sources, such as charts, procedures, forms and presentations, which helped in understanding the processes and practices of global sourcing in the companies. According to Eisenhardt (1989) and Yin (1981), the analysis based on different data collection methods provides stronger substantiation of construct and hypotheses.

Cross-case analysis was the chosen method of analysis. The following categories were defined previously: (1) Stage of the purchasing function and (2) subsidiary participation in the company global sourcing strategy. According to Eisenhardt (1989) and Yin (1981), cross-case analysis aims to search for the meaning of textual materials. It consists on a theoretical interpretation of the categories that were extracted from the researched material, also considering that these categories may be predefined, according to theory studied or even researcher preferences related to study objectives.

The data from the interviews were analyzed and grouped by similarity, in order to establish the relationship between the studied theory and practical methods adopted by companies researched. After extensive analysis of these data and comparison with the theories studied, companies were ranked based on the categories above written. Actions were presented to the points of improvement identified, making it possible to suggest a way to approach to global sourcing management subsidiaries in emerging countries.

\section{DATA ANALYSIS}

This chapter aims to present the results identified from the execution of the research, as the method described in the previous chapter. At first, it is presented the companies participating in the survey, according to Figure 3. Then it is described the categories of 
analysis defined previously, highlighting the practices observed, and, from these, presenting a classification of companies surveyed in accordance with the literature studied.

Figure 3 - Companies selected

\begin{tabular}{|c|c|c|c|c|c|c|c|c|c|c|}
\hline \multirow{2}{*}{ Conpany } & \multirow{2}{*}{ Segment } & \multirow{2}{*}{$\begin{array}{l}\text { Origini } \\
\text { country }\end{array}$} & \multirow{2}{*}{\multicolumn{2}{|c|}{\begin{tabular}{c|} 
Facilities: \\
Grop Brazil
\end{tabular}}} & \multicolumn{2}{|c|}{ Reventes } & \multicolumn{2}{|c|}{ Employees } & \multirow{2}{*}{$\begin{array}{l}\text { Representaticeuess } \\
\text { of import over tho } \\
\text { parchase: }\end{array}$} & \multirow{2}{*}{$\begin{array}{l}\text { Representativesess } \\
\text { of purchase over } \\
\text { the subsidtiary }\end{array}$} \\
\hline & & & & & Groap & Branil & Group : & Brani & & \\
\hline A & $\begin{array}{l}\text { Heating, ait-conditioning and } \\
\text { refigigeraticen }\end{array}$ & EUA & 67 & 2 & US $11 \mathrm{~B}$ & $\cos 0.5 \mathrm{~B}$ & 43.000 & 1.800 & $68 \%$ & $52 \%$ \\
\hline B & $\begin{array}{l}\text { Agricutural products, and } \\
\text { equipments }\end{array}$ & EUA & 28 & 3 & US $32 \mathrm{~B}$ & US $0.8 \mathrm{~B}$ & 61.278 & 3.505 & $45 \%$ & $60 \%$ \\
\hline c & Cranes and equipraents & EUA & 101 & 1 & US 3.7B & US $0.03 \mathrm{~B}$ & 12,900 & 350 & $40 \%$ & $70 \%$ \\
\hline D & $\begin{array}{l}\text { Gas, electricity and water } \\
\text { measurement and control }\end{array}$ & Germany & 23 & 1 & US $1,8 \mathrm{~B}$ & US $0.02 \mathrm{~B}$ & 3.00 & 200 & $20 \%$ & $34 \%$ \\
\hline E & $\begin{array}{l}\text { Equipment for beddting. } \\
\text { mintraining, and repaing roads }\end{array}$ & Germany & 8 & 1 & US $18 \mathrm{~B}$ & US $0.1 \mathrm{~B}$ & 4.500 & 330 & $25 \%$ & $69 \%$ \\
\hline F & Power tools & Germany & 6 & 1 & $\operatorname{tes} 2.3 \mathrm{~B}$ & US $0.3 \mathrm{~B}$ & 11.300 & 1950 & $45 \%$ & $55 \%$ \\
\hline G & Devator: & Germany & 9 & 1 & US $1.6 \mathrm{~B}$ & US 0.4B & 46.000 & 600 & $35 \%$ & $50 \%$ \\
\hline H & Power transformers, reactors & France & 12 & 1 & US $1.2 \mathrm{~B}$ & US $0.2 \mathrm{~B}$ & 6.000 & 450 & $40 \%$ & $54 \%$ \\
\hline
\end{tabular}

Source: Developed by authors

According to the selection criteria, the research focused on the evaluation of foreign MNCs with production units in Brazil. MNCs were selected from different countries of origin, segments, in order to obtain and analyze information about the practices established research topic in different markets. Companies selected are from developed countries origin. These are characterized as large companies, according to its sales and number of employees. Work in different countries, thus being competitors globally

According to Monczka and Trent (2003a), the GS strategy, understood as a function of the structure is adopted by large companies, which compete intensely on different continents and countries. Thus, it is possible to assume that the selected companies may be adopting strategies GS in their operations.

In the coming sections, it will presented by category of analysis, highlighting key practices observed, and correlating these with the theory studied in order to meet the proposed objectives for the study.

\subsection{Stage of the Purchasing Function}

According to the interviews, documents checked and practices identified, it was found out that the companies surveyed are characterized between stages 3 and 5 of the purchasing function, according to the model proposed by Monczka and Trent (2003a). 
Company "C" has, in its WHQ, specific structure for supply management, defining policies, guidelines, procedures, and establishment of supply contracts. However, the production units in different countries are autonomous regarding supply management. There is no format management and specific reporting to the WHQ. The results are assessed indirectly through accounting reports submitted between areas of controllership. The position adopted by the team of supplies in the WHQ, as well as other subsidiaries with larger scale production, is supportive of the needs created.

The Brazilian subsidiary seeks to adopt the same procedures and guidelines used in the WHQ, with adaptation to local support. The subsidiary uses, in part, global agreements to negotiate with company global suppliers that have subsidiaries in Brazil, involving the WHQ where applicable. Regularly conducts importation of key components from group overseas production units, according to the model of strategic decisions of supply proposed by Kotabe (1998). This mode represents about $20 \%$ of the total acquisition of the Brazilian subsidiary.

The company "E" has no structure to meet specific purchases worldwide. The group has eight units, which are unrelated to the definition and management of their supply strategies. The company has similar characteristic to the company " $\mathrm{C}$ " in terms of management. In both sites, WHQ and other production subsidiaries, materials management teams assume position of being available to assist the demands requested, but there is no proactive planning of any volumes consolidation and supply strategies more structured. Using intra-firm supply with importation from foreign subsidiary (KOTABE, 2008), the company, through licensing of production and marketing, meets the Brazilian market in two additional product lines to the scope of local production.

Companies "C" and "E" are classified in stage 3 of the purchasing function, which, as Monczka and Trent (2003a), companies started having a perspective of international shopping, markets and potential opportunities are mapped worldwide, and proactive measures are incorporated to supply strategy.

In companies "A", "D", "G" and "H" was identified specific structure at WHQ, with direct involvement of high-level executive leadership in the process, team management experts to provide definition policies, procedures and management strategies of global supply. There are alignments of objectives and annual targets, as well as monitoring the results on a monthly basis. Companies "A" and " $\mathrm{H}$ " use also purchasing offices in low-cost countries, aiming to exploit comparative advantages. The company "G" adopts also supply committee for setting and reviewing the strategy. 
There is development of global supply agreements for key raw materials, components, subassemblies and assemblies applied in the final products, and guidance to these subsidiaries for adoption, as well as prioritization for providing intra-firm. However, it is no mandatory to use these contracts. If there is no advantage in cost, quality, or technology, or even due to legal restrictions in the country where the subsidiary is located, the subsidiary has autonomy to address its supply strategy locally, being necessary only formalize the reasons to the WHQ.

Respondents of the subsidiaries of companies "A", " $D$ ", "G" and " $H$ " claim that the agreements did not benefit the Brazilian subsidiary. Additionally there are significant difficulties in establishing a forecast of production and sales accurately in order to reduce the impact brought by inventory purchase commitment. It is consensus between respondents that greater product standardization is required in order to increase utilization of global supply agreements.

In companies "A", "D", “G” and " $H$ ", it was observed low global alignment between functional groups for product development. Although there are product development centers, production units have autonomy to design and/or adapt products according to the local market needs. The lack of standardization of product and production between different subsidiaries was highlighted by respondents as a point of significant difficulty to expand global consolidation strategy for acquisition.

According to Monczka and Trent (2003a), stage 4 of the purchasing function includes integration and coordination strategies through GS purchasing teams allocated in different countries, as well as information systems with global interaction. With a high level of professional knowledge and skills in the supply management area, solid mechanisms of coordination and communication of supply management, centralized structure for overall coordination of activities, and senior executive responsible for the management and leadership strategies. It is understood, from the information above, that companies " $\mathrm{A}$ ", " $\mathrm{D}$ ", "G" and " $\mathrm{H}$ " fall into line at this stage.

In companies " $B$ " and " $F$ " it was observed equivalent existence of typical global sourcing strategy structure and processes as verified in the companies "A", "D", "G" and " $H$ ". The company " $F$ " has management and control system distinct from the others. The development of new product, supplier, or even technical changes is centralized in the WHQ, with the participation of cross-functional teams (Marketing, Engineering, Manufacturing, Quality, and Supply Chain) and contribution of subsidiaries. There is no local autonomy for managing in terms of product or even sourcing strategy. It shall be prior agreed and 
established by the WHQ. Company "B" has a special structure for supply management, divided by commodities.

There are global demands consolidation, revision and establishment of strategies with effective participation of subsidiaries. Committees are used to provide operational and executive level, which ensure the effectiveness of strategic alignment. According to the respondent "the strategy addresses the global sourcing, not the opposite" (verbal information). The Brazilian subsidiaries of companies " $\mathrm{B}$ " and " $\mathrm{F}$ " import around $45 \%$ of the volume of their purchasing volume, through intra-firm model using WHQ or other subsidiaries, or even through independent suppliers, attending global contracts developed by WHQ.

Companies "B" and "F", due to have centers of research and development, adopt global product standardization, centralization of product development, global sourcing management strategy, working in multifunctional teams and having participation of subsidiaries in the information provision are classified in stage 5 of the purchasing function, as proposed by Monczka and Trent (2003a). Highlights the supply management with global focus, where the reporting of results is concentrated in the WHQ.

Respondents from companies "A", "B", "C", "D", "F", "G" and "H" pointed out as major risks and obstacles to the expansion GS strategy, low accuracy in forecasting production and sales, due to the impact on inventory as well as the lack of products on the market, the difficulty in establishing trade agreements that are beneficial to all subsidiaries. Beyond that, the restrictions imposed by the government to protect the industry and domestic production are corroborated in studies presented by Bernard and Rajagopal (1994), Monczka and Trent (2003a), Kotabe and Murray (2004), Quintens et al. (2006), Nassimbenis (2006), Lintukangas, Peltola and Virolainen (2009), Hartmann, Trautmann and Jahns (2008), Hultman et al. (2012).

Additionally, it was reported (except for companies " $B$ " and " $F$ ", due to its format management) lack of vision and alignment in the enterprise related to global strategies, and a lack of synergy between the functional areas for results consolidation between different projects.

In general, business units allocated in different countries shall cover its geographic market demands and generate necessary profit. If the production subsidiary attends global programs and it brings negative result to the local operation, there is no specific reporting channel to be used in order to justify that result was not attended because of this global 
programs. This point was not observed in the literature studied, deserves special mention because of its importance and impact on the expansion strategy of GS.

\subsection{Subsidiary participation in the company Global Sourcing strategy}

In the literature review, it was not possible to identify studies that suggest a format for the participation of different production units in relation to the main strategy of the company GS, aiming to provide greater adherence to this form of management, enabling also greater assertiveness in defining strategies and actions.

Thus, from the definition of GS strategy as integration and coordination of supply strategies globally, observing and meeting the local requirements and characteristics (MONCZKA; TRENT, 2003a; KOTABE; MURRAY, 2004; QUINTENS et al. 2006 apud HULTMANN et al., 2012; NASSEMBINI, 2006; LINTUKANGAS; PELTOLA; VIROLAINEN, 2009; HULTMAN et al., 2012), and the main objective of exploring the competitive advantages (skills in $\mathrm{R} \& \mathrm{D}$, production and marketing) and comparative advantages (cost labor, mineral resources, government incentives) of different countries. Both in internal processes and in suppliers (MONCZKA; TRENT, 2003a; KOTABE; MURRAY, 2004), it was defined three criteria's for the classification of subsidiaries valued at terms of participation in the GS core strategy of the company, as follow:

1. Local supply management is fully integrated into the GS strategy: subsidiary participates in the definition of the overall objectives, features local approach in order to converge with studies and global sourcing strategies;

2. Local supply management is partially integrated into the GS strategy: subsidiary participates indirectly in the definition of the overall objectives, features local approach in order to partially converge with studies and global sourcing strategies;

3. Local supply management is not integrated into the GS strategy: subsidiary does not participate in defining the overall objectives, does not have local approach in order to converge with studies and global sourcing strategies.

Through the practices observed in the companies surveyed, it was found out that most part of the sample has local supply management partially integrated with the company strategy for GS, reactive to the demands of the WHQ, being represented by subsidiaries "A", "D', "G" and "H" (Figure 4). In these subsidiaries, as previously detailed, there is action by the WHQ and the definition of general strategies supply globally, targets and objectives in 
terms of supply as well as review of the strategy. However, due to the format of strategic management at the global level, where it is not mandatory the use of global agreements with independent suppliers or even intra-firm supply, it was found out that the subsidiaries operates partially with the WHQ as to the extent the supply strategy. The production units operate only to attend and report what is demanded by WHQ.

Part of the non-adherence of global agreements is linked to projects and previous experiences, where the subsidiary got no advantage in attending these contracts, and it is understood that the condition would remain the same. It was not highlighted by respondents, the performing of new feasibility studies that validate the above assumption or even submission to the WHQ the commercial target conditions in order to have benefits of global strategy. Additionally, there are the difficulties linked to accuracy programming, reflecting in inventory, longer lead-time between production and delivery of components.

Figure 4 - Subsidiary participation in the company global sourcing strategy

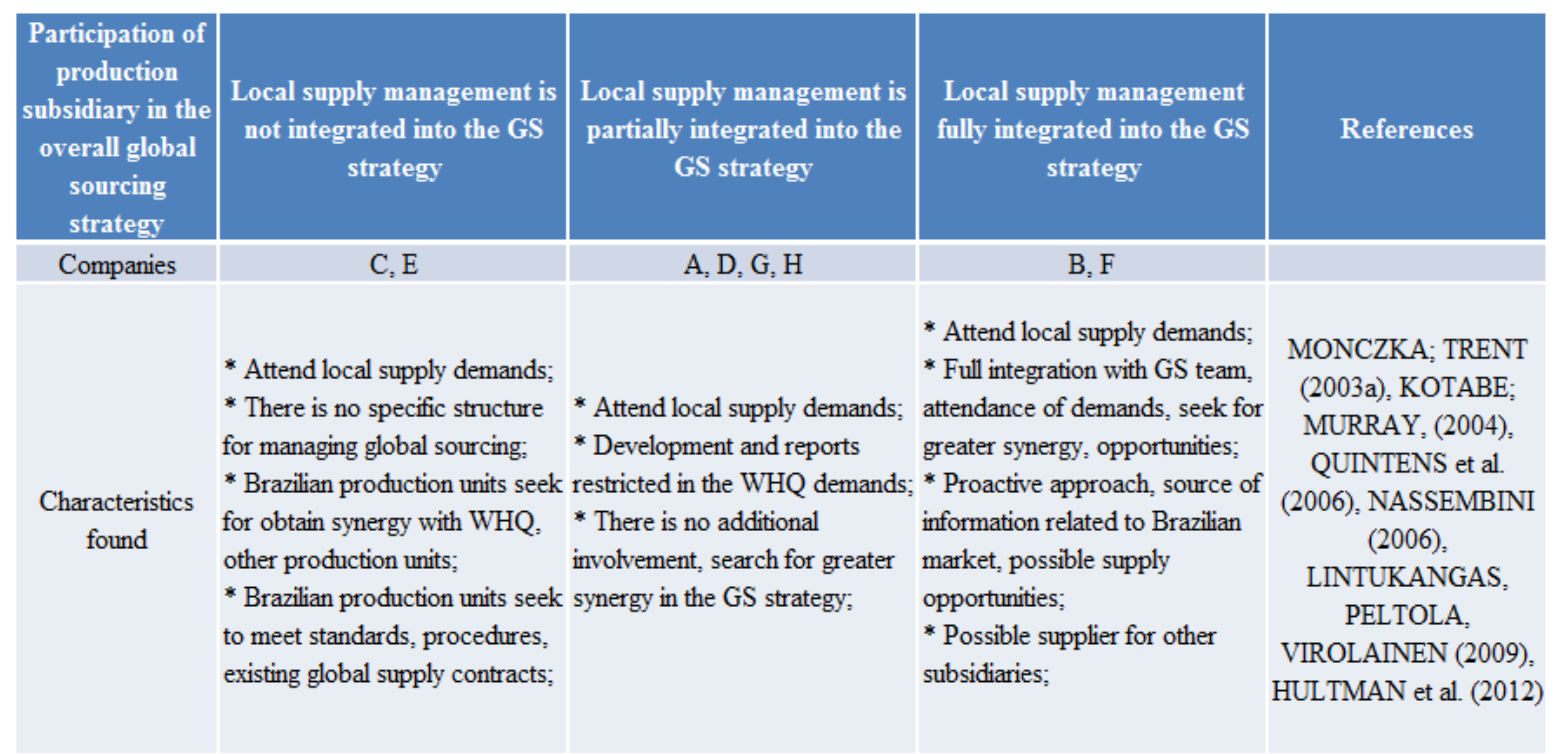

Source: Developed by the authors

The strategy of the production subsidiary in attending only what is required, fosters good relationships and image within the company, less questioning and additional demands. However, in the other hand, it is understood, based on the bibliographies studied, that if the subsidiaries, in special the ones based in emerging economies like Brazil, or even low-cost countries, does not seek for having stronger ties in with the company global supply strategies, company may have potential return from GS strategy reduced. 
Companies "C" and "E" as previously detailed, have no strategy for managing GS. Thus, in terms of local supply management, it is classified as non-integrated strategy for GS, not by their approach, but the strategy of their companies.

The production subsidiaries of companies " $B$ " and "F", depending on the size of management with greater interaction and service strategies global supply, are classified with participation in the management of local supply fully integrated strategy to GS.

Except for company "B", it was not identified the assessment of the subsidiaries related to technical feasibility, commercial and logistics companies installed to meet the demands of other units of the group. There is a general sense that Brazil is not competitive to attend global contracts, however, it was not identified structured process to validate this condition, or even the intention to perform it, without any specific demand. On the other hand, there is a little initiative on the part of the WHQ of these companies that require the subsidiaries to conduct assessments on their country.

Usually, efforts are limited to understand and consolidate worldwide demand, suggest the use of global agreements, and review in cases where they do not occur. Thus, it is not proportionate to the strategic management of supply, usually allocated in the WHQ, a greater understanding of the levels of competitiveness of Brazil in different groups of commodities purchased. Having the same approach installed by subsidiaries in other countries, the potential to obtain comparative advantages (MONCZKA; TRENT, 2003a; KOTABE; MURRAY, 2004) tends to decrease.

\subsection{Proposition of Global Sourcing management to subsidiaries based on emerging market}

Based on the literature studied in relation to the strategy of GS, as well as management practices observed during the visits and interviews, still observing the limitations of the method and the study, it was considered appropriate to suggest some actions in order to assist supply managers in obtaining better alignment with its parent as the global sourcing strategy.

It is consensus that the supply management in production subsidiary should first meet the procedures, rules, forms of results consolidation defined by the organization. This condition is essential for cooperation with the organization's strategies, and being met by group subsidiaries surveyed.

From this initial condition, it is suggested that the production subsidiary seek to establish a closer relationship with the management of global supply, usually allocated in the 
WHQ, presenting to them business format in Brazil, which are the main products produced and local regulations, seeking to benefit from global agreements. It is important to have understanding, on the part of the WHQ, as the legal limits, direct and indirect taxes by the country for imports of raw materials, components, assemblies and subassemblies. Due to the large number of subsidiaries in the organization, and the difficulties related to language and other cultural factors, the correct understanding regarding to the restrictions of each country to supply may be impaired. Figure 5 represents the current approach and proposal, observing best practices in terms of strategy GS.

Figure 5 - Approach of the production subsidiary in relation to the strategy of Global Sourcing

Current

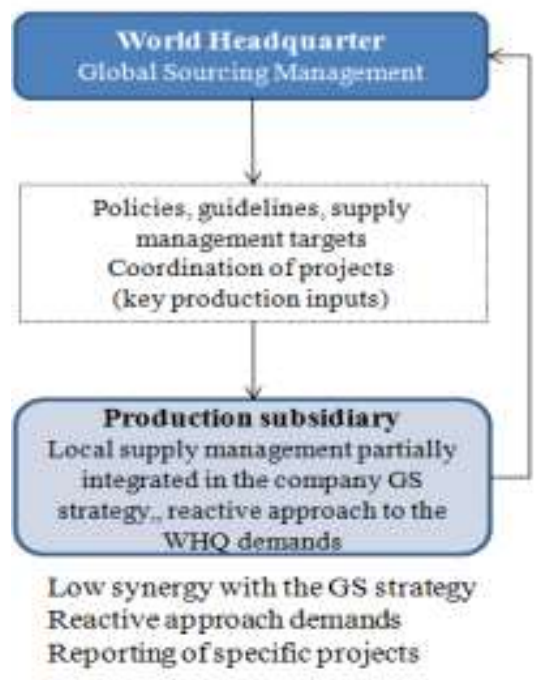

Proposal

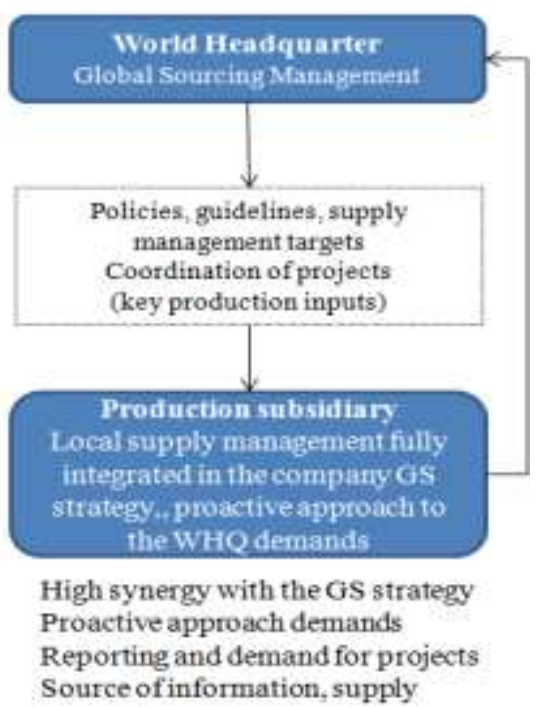

Source: Developed by the authors

From this alignment, it is suggested that using the standard reporting of the organization, the subsidiary consolidate acquisition information related to raw materials, components, sub-assemblies and assemblies, representatives in terms of total spend, technical complexity. And it be submitted, with specific targets in terms of total cost, quality, delivery, to the GS team in order to them perform necessary analysis, provide information and support to use global supply strategies and agreements.

Thus, it is understood that there is a significant possibility of having extension of the supply strategy. Additionally, in order to standardize the management activities of supply and obtain guidance for consolidation and convergence demands and global service, it is suggested to review the processes of evaluation and selection of suppliers, including, where possible analysis in relation to the WHQ supply options (current supplier base). This 
condition is likely to lead to the production unit and the management of global supply greater understanding of the level of competitiveness of production inputs evaluated.

Aiming to increase the possibility of comparative advantage for the organization, it's suggested that local supply management should seek to establish alignment with the overall management of supply for prioritization and evaluation of companies in Brazil with the potential to supply other units of the group. The extent of this activity, with proper coordination, alignment and direction information can bring greater understanding of the opportunities of meeting the global demands from different regions. It is understood that this process can be an important source of information to the consolidation of supply strategy decisions.

The above points suggest modification in the approach of subsidiary supply management. However, for greater success in the overall supply strategy, synergy between the functions of marketing, R\&D and Manufacturing (KOTABE, 1998) are expected. Understanding the importance of strategy GS, supply management managers of the subsidiaries may suggest that the actions of alignment proposed above, with the necessary adjustments could be implemented by other areas, achieving greater standardization and alignment strategies Marketing, R\&D, Manufacturing and Supply may. From this, meet the Stage 5 of the purchasing function proposed by Monczka and Trent (2003a), with the formation of functional teams for product development, with standardization and product manufacturing.

The change of production subsidiary posture, proposed above, going for a more proactive approach, with greater alignment with the WHQ and propose of complementary activities that enable the benefit to the company, will not necessarily change the overall strategy of the organization, but can provide the production unit benefits in cost, quality, technology, and services related to global agreements. Additionally, it is possible to improve subsidiaries visibility in the organization, as well as provide greater local trust on decisions related to the supply format.

It is understood, however, that this is a process with relative difficulty of implementation and acceptance, however, it is suggested here a change about thinking and acting, looking to be connected with the best management practices of global supply, verified in the current literature. 


\section{CONCLUSIONS}

This article aimed to analyze how the production subsidiaries of foreign multinational companies, operating in Brazil are inserted and participate in the global sourcing strategy of the organization.

From the results, it was observed that most of the selected companies have structure, processes and practices of global sourcing. In smaller representation, it was verified procurement practices as part of international sourcing strategy, according to the model proposed by Monczka and Trent (2003a).

It was verified broad allocation of resources to use global supply agreements (or even intra-firm outsourcing), but not the obligation to use these strategy in the majority part of the companies surveyed. Subsidiaries are more oriented to attend what is requested.

Noteworthy is the lack of concern, direction, and control for the global strategic management team of the companies evaluated in terms of getting information about the feasibility of supply originated from countries where its subsidiaries are allocated, referring here, more specifically, to the case of the Brazilian subsidiaries. Due to position assumed by WHQ, and the approach current adopted by the production subsidiaries assessed to be more positioned to react to demands. It is observed that MNCs may be losing good opportunities to expand their understanding about the options meeting the demands of global comparative advantage, due to no assessment processes and analysis being conducted with the production sources located in these countries.

\section{REFERENCES}

BNDES. BANCO NACIONAL DE DESENVOLVIMENTO ECONÔMICO E SOCIAL. Classificação de empresas por porte. 2012. Available in: <http://www.bndes.gov.br.

BARNEY, J.B. Firm resources and sustained competitive advantage. Journal of Management, v. 17, p. 99-120, 1991.

BARRAT, M.; CHOI, T.Y.; LI, M. Qualitative case studies in operations management: Trends, research outcomes, and future research implications. Journal of Operations Management, v. 29, p. 329-342, 2011.

BERNARD, K.N.; RAJAGOPAL, S. Global procurement: motivations and strategy. Marketing intelligence and Planning, v. 12, p. 4-17, 1994.

EDGELL, J.; MEISTER, G.E.; STAMP, N. Global Sourcing Trends in 2008. Strategic Outsourcing: An International Journal, v. 1. p. 173-180, 2008. 
EISENHARDT, K.M. Building theories from case study research. Academy of Management Review, v. 14, p. 532-550, 1989.

HARTMANN E.; TRAUTMANN G.; JAHNS C. Organizational design implications of global sourcing: a multiple case study analysis on application on control mechanisms. Journal of Purchasing and Supply Management, v. 14, p. 28-42, 2008.

HULTMAN, J.; JOHNSEN, T.; JOHNSEN, R.; HERTZ, S. An Interaction approach to global sourcing: a case study of IKEA. Journal of Purchasing \& Supply Management, v. 18, p. 9$21,2012$.

KOTABE, M. Efficiency versus Effectiveness orientation of global sourcing strategy: a comparison of U.S. and Japanese multinational companies. Academy of Management Executive, v. 12, p. 107-119, 1998.

KOTABE, M.; MURRAY, J.Y. Global sourcing strategy and sustainable Advantage. Industrial Marketing Management, v. 33, p. 7-14, 2004.

KRIPPEL, M.; ANTUNES, J.A. Construção da Matriz de Posicionamento Estratégico de Materiais: Um estudo de caso na indústria metal mecânica. In: XXIII ENEGEP, Proceedings..., - Ouro Preto, MG, Brasil, 2003.

LINTUKANGAS, K.; PELTOLA, S.; VIROLAINEN, V. Some issues of supply management integration. Journal of Purchasing and Supply Chain Management, v. 15, p. 240-248, 2009.

MONCZKA, R.; TRENT, R. Understanding Integrated Global Sourcing - a framework and Case Study. International Journal of Physical Distribution \& Logistics Management, v. 23, p. 25-34, 2003a.

Understanding integrated global sourcing. International Journal of Physical Distribution \& Logistics Management, v. 33, p. 607-629, 2003 b.

NASSIMBENI, G. International sourcing: empirical evidence from a sample of Italian firms. International Journal of Production Economics, v. 103, p. 694-706, 2006.

PICCHIONI, C. N. Abordagem do global sourcing nas subsidiárias de multinacionais no Brasil. Tese (Mestrado em Administração). Programa de Pós-Graduação em Administração, Universidade de São Paulo, São Paulo, 2010.

RIGGS, D.; ROBBINS, S. Supply Management Strategies. HSM Management Book Summary 2, 2001.

SEBRAE. SERVIÇO BRASILEIRO DE APOIO ÀS MICRO E PEQUENAS EMPRESAS. Classificação de empresas por número de funcionários. 2012. Available in: http://www.sebrae-sc.com.br.

STEINLE, C.; SCHIELE, H. Limits to global sourcing? Strategic consequences of dependency on international supplier: Cluster theory, resource-based view and case studies. Journal of Purchasing and Supply Management, v. 14, n. 1, p. 3-14, 2008. 
TRAUTMANN, G.; BALS, L.; HARTMANN, E. Global sourcing in integrated network structures: The case of hybrid purchasing organizations. Journal of International Management, v. 15, n. 2, p. 194-208, 2009.

WHITELOCK, J. Theories of internationalization and their impact on market entry. International Marketing Review, v. 19, p. 342-347, 2002.

WORLD INVESTMENT REPORT. United Nations Publication. 2011.

YIN, R.K. The case study crisis: some answers. Administrative Science Quarterly, v. 26, p. 58-65, 1981.

Originais recebidos em: 10/03/2014

Aceito para publicação em: 15/10/2014 